\title{
PEMAHAMAN KONSEP MATEMATIKA SISWA DALAM MENYELESAIKAN MASALAH BANGUN DATAR
}

\author{
Fatqurhohman \\ Program Studi Pendidikan Matematika, Universitas PGRI Banyuwangi \\ e-mail:frohman86@gmail.com
}

\begin{abstract}
This research is meant to describe the students' understanding of Mathematics Concept related to non-routine problem in contour Shapes. This research is a qualitative research. The subject of this research are 25 students of fourth (VI) grade of SDN Mojorejo 02 Kota Batu. The data are collected through students' response on a test given. Based on the result of this research shows that students are still unable to use Mathematics concept well in solving some problems (still tent to be procedural), students are still unable to compare by presenting alternative solution aside from response obtained, students' mastery and understanding concept of Mathematics in solving non-routine questions are still low. Teachers are hoped to be able to provide non-routine questions in order to allow students to be accustomed with and develop ability in relation to problem solving
\end{abstract}

Key Words: The understanding of Mathematics Concept, Non-Routine Questions, and Contour Shapes.

\begin{abstract}
Abstrak: Artikel ini bertujuan untuk mendeskripsikan pemahaman konsep matematika siswa kaitannya dengansoal non-rutin pada materi bangun datar. Jenis penelitian ini adalah kualitatif. Subjek penelitian adalah siswa kelas IV (empat) SDN Mojorejo 02 Kota Batu yang berjumlah 25. Data diperoleh melalui hasil respon/jawaban tes siswa. Berdasarkan hasil yang diperoleh bahwa siswa belum dapat dengan baik menggunakan konsep-konsep matematika dalam menyelesaiakan masalah (masih cenderung prosedural), siswa belum dapat membandingkan dengan menyajikan alternatif solusi yang lain dari respon yang diperoleh, penguasaan dan pemahaman konsep matematika dalam menyelesaikan soal nonrutin masih rendah. Diharapkan guru dapat memberikan soal non-rutin agar siswa terbiasa dan mengembangkan kemampuannya kaitannnya dengan pemecahan masalah.
\end{abstract}

Kata Kunci : Pemahaman Konsep Matematika, Soal non-rutin, dan Bangun Datar

\section{PENDAHULUAN}

Matematika merupakan ilmu yang perlu dipahami oleh setiap orang, terutama siswa yang berada pada jenjang pendidikan formal. Sedangkan hakikat dari matematika adalah siswa dihadapkan dalam belajar matematika pada masalah tertentu berdasarkan konstruksi pengetahuan yang diperolehnya ketika belajar dan akan berusaha memecahkannya (Hamzah, 2010). Siswa dapat peka terhadap matematika hanya jika mereka memahami konsep dan menginterpretasi- kannya. Sehingga untuk mengetahui seseorang memahami suatu konsep apabila seseorang dapat menyatakan pengertian konsep dengan bahasanya sendiri.

Salah satu kunci keberhasilan dalam belajar matematika adalah penguasaan konsep. Menurut Sagala (2009), konsep merupakan suatu ide abstraksi yang mewakili objekobjek, kejadian-kejadian, kegiatan-kegiatan, atau hubungan-hubungan yang mempunyai atribut-atribut yang sama. Hal ini dikarenakan berbagai konsep matematika memiliki 
keterkaitan yang kuat antar satu konsep dengan konsep lainnya. Apabila siswa belum menguasai kemampuan dasar dalam memahami matematika tersebut maka tujuan pembelajaran yang diharapkan tidak mungkin tercapai dan dipastikan bahwa siswa akan mengalami kesulitan dalam merancang penyelesaian dan melaksanakan rancangan penyelesaian masalah. Sehingga dengan pemahaman konsep, siswa akan mampu mengaitkan serta memecahkan permasalahan dengan berbekal kemampuan dasar melalui konsep yang sudah dipahaminya (O'Connell, 2007).

Menurut Duffin dan Simpson (1997) pemahaman adalah kesadaran dari struktur mental yang internal. Sedangkan menurut Sierpinska (2005) pemahaman merupakan suatu hal yang nyata sebagai pengalaman mental seseorang yang potensial atau aktifitas kognitif yang berlangsung pada waktu yang lebih panjang. Dengan adanya pemahaman memudahkan terjadinya transfer ilmu (Hiebert dalam Barmby et.al, 2009). Sehingga pemahaman memerlukan kemampuan untuk mengakses beberapa pengetahuan yang relevan (Shirkey, 2003).

Palinscar dan Brown (1984) menyatakan bahwa pemahaman dapat diaplikasikan secara prosedural, konseptual, ataupun proses. Menurut Ghazali \&Zakaria (2011), siswa dengan tingkat pengetahuan konseptual mampu memecahkan masalah yang mereka tidak pernah dijumpai sebelumnya. Oleh karena itu, reformasi dalam mengajar diperlukan untuk meningkatkan pemahaman konseptual siswa untuk meminimalkan penggunaan algoritma dan menghafal. Menurut Mousley (2004), tujuan dari kegiatan mengajar yang paling penting adalah untuk membangun pemahaman matematikasiswa di kelas. Karena pemahaman matematika dapat menumbuhkan keaktifan siswa dalam mencari ide-ide matematikanya (Kilpatrick \& Swafford, 2002).

Kyle \& Lovin (2012) menyatakan bahwa solusi yang dipakai dalam memecahkan masalah/hambatan dalam proses belajar mengajar adalah dengan mengidentifikasi masalah yang dihadapi.Michelle, J \& Beswick, K (2010) berpendapat bahwa bekerja secara interaktif dalam lingkungan yang mendukung dapat meningkatkan pemahaman matematika, kaitannya dengan meningkatnya kepercayaan dalam kemampuan mereka sendiri yang dirancang secara individual. Pada tingkat pemahaman yang mendalam siswa mulai mampu untuk membuat keterkaitan antar ide-ide matematika dan membuat generalisasi dari suatu konsep (Potter \& Kustra, 2012). Sehingga pemahaman matematika siswa dapat dilihat dari performa siswa dalam memberikan respon dari asesmen yang diberikan guru.

Menurut Rahaimah \& Noraini (2013) bahwa gambaran tentang pentingnya membuat pendekatan yang diberikan oleh guru tepat sasaran berdasarkan pemahaman yang dimiliki siswa. Sejalan dengan pendapat Almir et. al (2013) bahwa apabila siswa benar-benar memahami masalah, mereka bisa menjelaskan, menafsirkan, menerapkan, memiliki perspektif, berempati, dan memiliki pengetahuan diri yang meliputi penggunaan dan aplikasi dalam situasi otentik berdasarkan pengetahuan konseptual dan prosedural. Sehingga penggunaan waktu pada setiap pelajaran yang direncanakan memungkinkan siswa untuk menguasai keterampilan dasar dalam menggunakan informasi yang dimiliki ketika merencanakan strategi solusinya (Penlington, 2011).

Alasan pemahaman konsep matematika penting bagi siswa adalah dasar pengetahuan yang menjadi tujuan dari belajar matematika awal (Mulligan \& Mitchelmore, 2009).Dalam menilai atau mendeskripsikan pemahaman 
siswa tidak dilihat dari benar atau salah jawabannya tetapi lebih penting mengetahui alasan siswa dalam memberikan respon/ jawaban dari masalah yang diberikan (Romero \& Mari, 2006). Sehingga belajar matematika di sekolah dasar tidak hanya diarahkan pada peningkatan kemampuan siswa dalam berhitung, tetapi juga diarahkan kepada peningkatan kemampuan siswa dalam pemecahan masalah (Problem Solving).

Menurut Polya (1973) pemecahan masalah merupakan usaha mencari jalan keluar dari suatu kesulitan/permasalahan untuk mencapai suatu tujuan yang tidak dapat dicapai secara langsung. Sedangkan Siswono (2008) menyatakan bahwa pemecahan masalah merupakan suatu proses atau upaya individu untuk merespon atau mengatasi permasalahan ketika suatu jawaban atau metode jawaban belum jelas. Sejalan dengan pendapat Sudarman (2010) menyatakan bahwa pemecahan masalah merupakan hal penting yang dilakukan dalam belajar matematika di kelas. Salah satu aspek penting yang mendasari pemecahan masalah adalah kemampuan siswa dalam memahami suatu permasalahan terutama pada pemahaman konsep matematika. Selain itu, tingkat kesulitan soal pemecahan masalah harus di sesuaikan dengan tingkat kemampuan siswa. Sehingga dapat mengarahkan siswa untuk menggunakan konsep-konsep matematika yang dipelajari dalam pemecahan masalah. Pemecahan masalah meliputi masalah tertutup dengan solusi tunggal, masalah terbuka dengan solusi tidak tunggal dengan berbagai cara penyelesaian.

Menurut Orton (2004: 141), pemberian masalah terbuka sangat baik digunakan dalam pembelajaran matematika. Sedangkan menurut Emilya (2010), masalah terbuka dapat memberikan pengaruh potensial yang positif dalam memunculkan ide-ide dan menemukan solusi/ cara penyelesaian jawaban yang beragam. Sehingga pemecahan masalah menjadi fokus penting dalam belajar matamatika terutama di sekolah dasar. Polya (1973) menyatakan bahwa ada 4 (empat) tahap dalam pemecahan masalah yaitu memahami masalah, merencanakan penyelesaian atau membuat model matematika, menyelesaikan masalah sesuai rencana, melakukan pengecekan kembali.

Dalam artikel ini, peneliti bermaksud menggali pemahaman konsep matematika siswa sekolah dasar. Indikator pemahaman konsep matematika mengacu pada pendapat Kilpatrick (2001) yaitu menyatakan ulang sebuah konsep yang dipelajari; menggunakan, memanfaatkan, dan memilih prosedur; memberi contoh dan non contoh; meng-aplikasikan konsep atau algoritma pemecahan masalah; membandingkan dengan menyajikan contoh dalam berbagai representasi. Dengan indikator tersebut, peneliti dapat menggali pemahaman konsep matematika siswa kaitannnya dengan me-nyelesaikan soal non-rutin pada materi bangun datar. Sehingga peneliti mengambil judul "Pemahaman Konsep Matematika Siswa Dalam Menyelesaikan Masalah Bangun Datar".

\section{METODE}

Penelitian ini termasuk jenis penelitian deskriptif dengan pendekatan kualitatif. Subjek penelitian ini adalah siswa kelas IV SDN Mojorejo 02 Kota Batu yang berjumlah 25 siswa. Data diperoleh melalui hasil respon jawaban soal tes siswa, hasil wawancara, dan rekaman (video). Soal tes yang diberikan berbentuk soal non-rutin pada materi bangun datar. Sedangkan wawancara diperlukan untuk menggali atau mencari informasi yang lebih mendalam dari hasil respon jawaban siswa terhadap soal tes. Rekaman (video) digunakan untuk merekam informasi respon secara lisan maupun tertulis siswa. Dengan cara ini akan dapat membantu dan memperoleh informasi yang lengkap dalam menganalisis hasilnya. 


\section{HASIL DAN PEMBAHASAN}

Untuk mengetahui pemahaman konsep matematika siswa, diberikan soal pemecahan masalah menggunakan soal non-rutin. Sesuai dengan pandangan O'Connell (2007) bahwa dengan pemahaman konsep, siswa akan lebih mudah dalam memecahkan permasalahan karena siswa akan mampu mengaitkan serta memecahkan permasalahan tersebut dengan berbekal konsep yang sudah dipahaminya. Karena pemahaman konsep merujuk pada keaktifan siswa mencari ide-ide matematika (Kilpatrick \& Swafford, 2002). Selain itu, pandangan yang serupa dinyatakan (Almir et. al, 2013) bahwa apabila siswa benar-benar memahami masalah, mereka bisa menjelaskan, menafsirkan, menerapkan, memiliki perspektif, berempati, dan memiliki pengetahuan diri dalam situasi otentik dari pengetahuan konseptual dan prosedural.

Pemecahan masalah adalah tugas tertulis yang dikembangkan berupa soal non-rutin dengan menggunakan materi bangun datar. Hasil tugas tertulis yang dikembangkan ditindak lanjuti dengan wawancara yang bertujuan untuk menggali dan mengungkap pemahaman konsep matematika siswa. Wawancara dilakukan pada saat subjek sedang menyelesaikan masalah yang diberikan. Soal non-rutin tersebut adalah sebagai berikut.

Tentukan ukuran panjang dan lebar dari suatu persegipanjang yang luasnya 36 $\mathrm{m}^{2}$ ? Jelaskan jawabanmu!

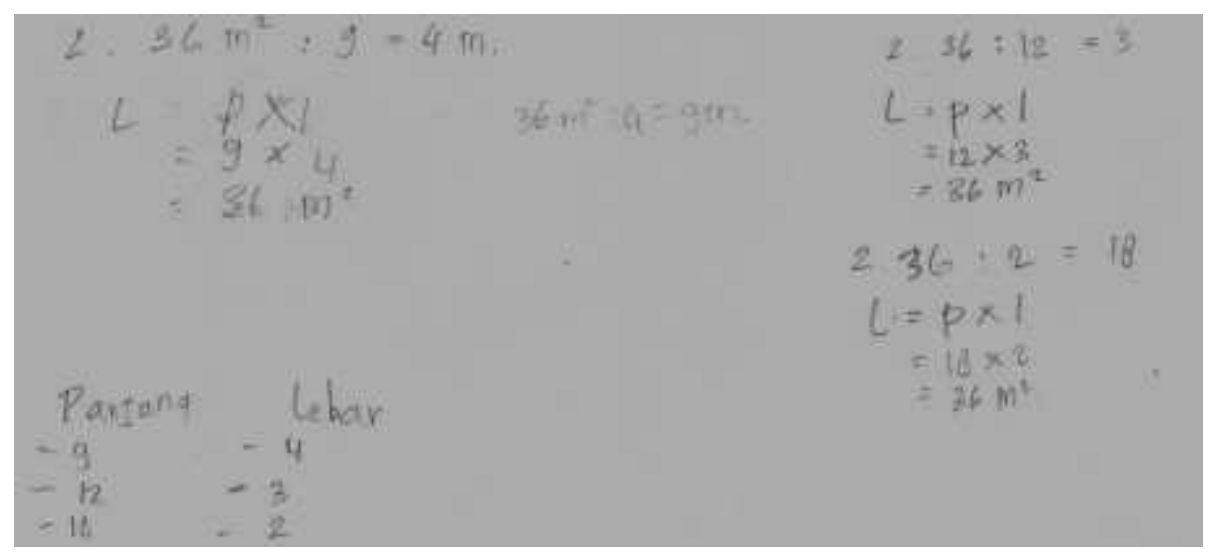

Gambar 3.1. Respon Siswa A

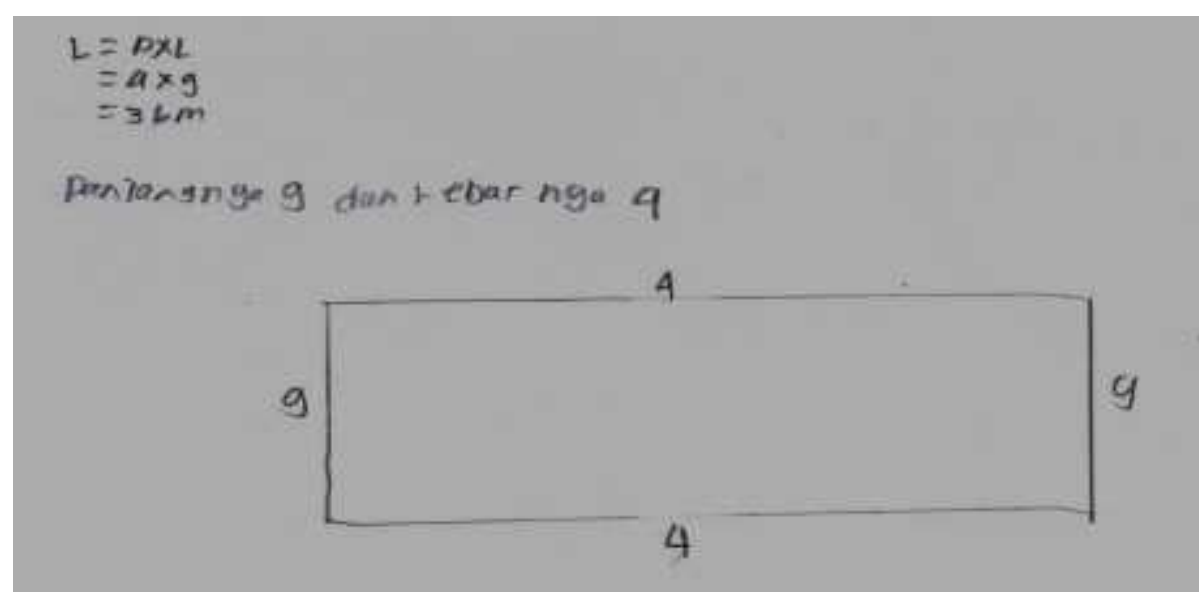

Gambar 3.2. Respon Siswa A

Siswa A, dapat menyelesaikan masalah dapat memberikan alasan tetapi belum jelas. yang diberikan lebih dari satu jawaban dan Selain itu mereka belum dapat mengaitkan 
konsep-konsep yang sesuai dalam menyelesaikan permasalahan yang diberikan. Apabila soal-soal non-rutin diberikan secara berkelanjutan diyakini dapat mengembangkan ideide yang dimiliki dalam menyelesaikan permasalahan tersebut. Sedangkan siswa B, belum dapat menyelesaikan masalah yang diberikan lebih dari satu jawaban. Akan tetapi siswa B sudah dapat memberikan alasan secara jelas yang mengarah ke hasil jawabannya melalui masalah yang diketahui maupun dengan bentuk gambar.

Berdasarkan indikator pemahaman konsep matematika yang mengacu pada pendapat Kilpatrick (2001) yaitu menyatakan ulang sebuah konsep yang dipelajari; menggunakan, memanfaatkan, dan memilih prosedur; memberi contoh dan non contoh; mengaplikasikan konsep atau algoritma pemecahan masalah; membandingkan dengan menyajikan contoh dalam berbagai representasi. Sehingga dapat diuraikan sebagai berikut.

Menyatakan ulang sebuah konsep yang dipelajari, dalam hal ini dikatakan bahwa siswa A dan siswa B sudah dapat mengenali hampir fakta, prinsip dan konsep yang menjadi prasyarat dalam menyelesaikan permasalahan dengan memberikan respon jawaban melalui rumus yang pernah dipelajari yaitu luas persegi panjang = panjang $\mathrm{X}$ lebar. Dengan berbekal pengalaman dan pengetahuan yang dimiliki, siswa dapat melakukan atau merencanakan penyelesaian dari masalah yang diberikan. Selanjutnya, dalam merencanakan penyelesaian dengan memilih konsep yang sesuai. Hal ini terlihat saat siswa B menggambarkan sebuah persegi panjang dengan ukuran panjang 9 dan ukuran lebar 4. Berbeda dengan siswa $\mathrm{A}$, dia hanya menuliskan rumus dan menentukan ukuran panjang dan lebar tanpa menggambarkannya. Sehingga dapat dikatakan bahwa siswa A dan siswa $\mathrm{B}$ memiliki pengetahuan yang berbeda dari sudut pandang memahami dan menyelesaikan permasalahan tersebut. Siswa A termasuk memiliki kemampuan dan pengetahuan pemahaman lebih tinggi daripada siswa B. Karena siswa A tanpa merepresentasikan melalui gambar dapat memberikan alasan dan jawaban lebih dari satu jawaban meskipun dari alasan yang diberikan belum jelas. Berbeda dengan siswa $\mathrm{B}$, sudah dapat mengarah pada alasan yang jelas dari respon jawaban yang diberikan meskipun hanya satu respon jawaban yang diberikan.

Pada indikator mengaplikasikan konsep atau algoritma pemecahan masalah, siswa $\mathrm{A}$ dan siswa B sudah dapat menggunakan prosedur yang direncanakan dalam menyelesaikan masalah yang diberikan. Pada siswa B, hanya dapat memberikan satu respon jawaban dengan alasan jelas mengarah ke respon jawaban. Sedangkan siswa A, dapat memberikan lebih dari respon jawaban akan tetapi belum dapat memberikan alasan yang kuat dari respon jawaban yang diberikan. Hal ini diyakini bahwa dari beberapa respon jawaban dan alasan yang diberikan, pemahaman konsep matematika yang dimiliki masih dikatakan kurang, karena mereka hanya menyelesaikan langsung pada rumus tanpa memberikan alasan yang kuat atau logis dari apa yang dikerjakan. Dengan demikian, siswa belum dapat dikategorikan dalam memberikan contoh dan non-contoh dengan mengaplikasikan konsep yang dipelajari. Apabila pemahaman konsep dalam belajar telah tercapai, maka siswa dalam menjawab soal dapat menguraikan terlebih dahulu definisi penggunaan rumus tersebut. Dengan kata lain siswa sedikit bercerita tentang konsep yang digunakan dalam penyelesaian soal tersebut.

Pada indikator membandingkan dengan menyajikan contoh dalam berbagai representasi, siswa sudah dapat memberikan hasilnya melalui perhitungan dari respon 
jawaban soal yang diketahui. Sebagai contoh siswa A, dia dapat menunjukkan hasilnya dengan membandingkan alternatif jawaban yang diperolehnya, seperti panjang1 $=9$ dan lebar1 $=4$; panjang $2=12$ dan lebar2 $=$ 3 ; panjang $3=18$ dan lebar3 $=2$. Berbeda dengan siswa $\mathrm{B}$, dia hanya memiliki satu jawaban sehingga untuk membandingkan hasil yang diperoleh dia tidak dapat melakukannnya.

Dari data yang diperoleh, salah satu penyebab kurangnya pemahaman konsep dalam pemecahan masalah adalah metode belajar maupun soal-soal yang diberikan oleh guru pada saat proses belajar mengajar. Sehingga berkurangnya respon siswa terhadap proses belajar mengajar disebabkan rendahnya partisipasi siswa dalam belajar di kelas, sehingga proses belajar mengajar di kelas kurang bermakna (Murray, 2011). Sebagai contoh siswa B yang hanya dapat menyelesaikan permasalahan dengan satu jawaban. Hal ini belum dapat memahami permasalahan yang diberikan dikarenakan pemahaman konsep matematika yang dimiliki masih kurang.

Penyebab pemahaman konsep matematika siswa seperti yang diuraikan, proses belajar mengajar yang digunakan guru adalah hanya membahas materi yang sedang dipelajari tanpa menanamkan konsep matematika kepada siswa melalui pemahaman secara mendalam, selain itu guru hanya memberikan soal-soal rutin yang hasilnya dapat diselesaikan secara prosedural. Sehingga secara tidak langsung siswa hanya dilatih pada keterampilan berhitung dan kecenderungan meng-hapalkan rumus yang ada. Hal ini yang menyebabkan matematika dianggap pelajaran yang sulit dan sampai sekarang masih ditakuti. Karena siswa menganggap bahwa matematika itu penuh dengan hapalan rumus dan angkaangka yang membingungkan.
Pemahaman konsep matematika kaitannya dengan pemecahan masalah dapat dilakukan dengan memberikan soal non-rutin, tujuannya agar siswa dapat terbiasa mengenali maupun memahami soal tersebut dengan menggunakan konsep matematika yang dimiliki. Perlu diperhatikan bahwa dalam menanamkan pemahaman konsep kepada siswa harus menyesuaikan dengan kemampuan yang dimiliki siswa. Selain itu siswa diharapkan sering mengerjakan latihan soal dan dituntut keaktifan belajar dikelas. Seorang pendidik (guru) haruslah memberikan kesempatan dan membebaskan para siswanya untuk memecahkan masalah secara mandiri, akan tetapi tetap mengacu pada kebenaran konsep yang ada.

\section{SIMPULAN}

Dari hasil pembahasan yang dipaparkan, maka diperoleh kesimpulan bahwa penguasaan dan pemahaman konsep matematika siswa dalam memahami dan menyelesaikan permasalahan masih rendah kaitannya dengan soal non-rutin. Hal ini ditunjukkan dengan penyelesaian siswa yang masih bersifat prosedural. Dengan kata lain siswa masih belum terbiasa/kesulitan dengan soal nonrutin. Sehingga pemahaman konsep matematika siswa perlu ditingkatkan dan dikembangkan kaitannya dengan soal nonrutin. Karena soal-soal tersebut diyakini dapat mempengaruhi pemahaman konsep matematika siswa. Dalam menanamkan pemahaman konsep kepada siswa harus menyesuaikan dengan kemampuan yang dimiliki siswa. Selain itu siswa diharapkan sering mengerjakan latihan soaldan dituntut keaktifan dalam belajar dikelas.

Dengan memperhatikan kemampuan siswa menerima materi yang diajarkan, maka pemahaman konsep dalam belajar mate- 
matika dapat dilakukan dengan cara sederhana dan menarik melalui pemecahan masalah dengan menggunakan soal nonrutin. Hal ini dikarenakan bahwa pemahaman konsep merupakan bagian yang terpenting

\section{DAFTAR PUSTAKA}

Anderson dan Krathwohl. 2001. A Taxonomy for leraning, teaching, and Assessing. United States: Addison Wesley Longman, Inc.

Enger, S.K. dan Yager, R.E. 2001. Assessing Student Understanding in Science. California: Corwin Press, Inc.

Hayat, B. 2008. Prinsip-Prinsip dan Strategi Penilaian di kelas dalam Assessment BerbasisKelas. Jakarta: Pusat Penilaian pendidikan, Badan Penelitian dan Pengembangan Depdiknas. Thompson, T. 2008. Mathematics Teachers Interpretation of Higher Order Thinking in Blooms Taxonomy dalam IEJME, Vol. 3(2), pp. 82-102.

McMahon, G. P. 2007. Getting the HOTS with what's in the box: Developing higherorderthinking skills within a dalamproses belajar matematika. Sehingga matematika tidak dianggap pelajaran yang sulit, karena penuh dengan hapalan rumus dan angka-angka yang membingungkan.

technology-rich learning environment. Thesis presented for the Degree of Doktor of Philosophy of Curtin University of Technology.

Miles, M. B dan Huberman, A. M. 1992. Analsisis data Kualitatif terjemah Rohidi, T. Jakarta: UI Press.

Moleong, L.J. 2009. Metodologi Penelitian Kualitatif. Bandung: Remaja Rosdakarya. Newman, M.A. 1983. Strategies for Diagnosis and Remediation. Sydney: Harcourt, Brace Jovanovich.

Newman, M.A. 1983. Strategies for Diagnosis and Remediation. Sydney: Harcourt, Brace Jovanovich.

Thompson, T. 2008. Mathematics Teachers Interpretation of Higher Order Thinkng in Blooms Taxonomy dalam IEJME, Vol. 3(2), pp. 82-102. 